D. H. LAWRENCE 



\title{
D. H. LAWRENCE
}

A Centenary Consideration

EDITED By PETER BALBERT

AND PHILLIP L. MARCUS

CORNELL UNIVERSITY PRESS

\author{
ITHACA AND LONDON
}


Copyright (C) $198 j$ by Cornell University Press

All rights reserved. Except for brief quotations in a review, this book, or parts thereof, must not be reproduced in any form without permission in writing from the publisher. For information, address Cornell University Press, 124 Roberts Place, Ithaca, New York $1485^{\circ}$.

First published 1985 by Cornell University Press.

International Standard Book Number 0-8014-1596-9 Library of Congress Catalog Card Number $84-45800$ Printed in the United States of America

Librarians: Library of Congress cataloging information appears on the last page of the book.

The paper in this book is acid-free and meets the guidelines for permanence and durability of the Committee on Production Guidelines for Book Longevity of the Council on Library Resources.

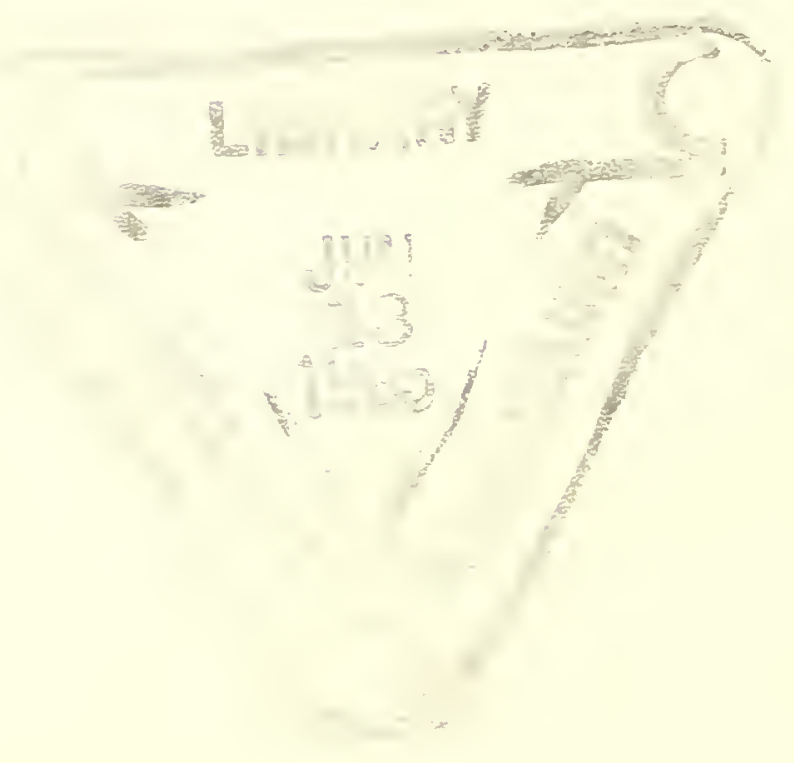


TO THE MEMORY OF OUR FATHERS

Bert Balbert (1911-1978)

Ben C. Marcus (1904-1983) 
Digitized by the Internet Archive in 2018 with funding from

The Arcadia Fund 